\title{
PENGEMBANGAN INSTRUMEN ANALISIS KESALAHAN UNTUK MENGUKUR CRITICAL THINKING SKILL BERDASARKAN KOMPETENSI INTI KURIKULUM 2013 Zaenal Arifin
}

\author{
Pendidikan Matematika, Universitas Majalengka \\ Jl. K.H. Abdul Halim No. 103, Majalengka \\ arifin1169@gmail.com
}

\begin{abstract}
Penelitian ini merupakan penelitian pengembangan $(R \& D)$ yang dibuat berdasarkan Kompetensi Inti Kurikulum 2013. Penelitian ini bertujuan untuk menghasilkan instrumen analisis kesalahan untuk mengukur critical thinking skills matematika siswa SMA yang valid dan reliabel, dan untuk mengetahui kemampuan critical thinking matematika siswa SMA setelah diberikan instrumen. Penelitian ini meliputi beberapa langkah, yaitu: (1) menyusun spesifikasi tes, (2) menulis soal tes, (3) menelaah soal tes, (4) melakukan uji coba tes, (5) menganalisis butir soal, (6) memperbaiki tes, dan (7) merakit tes. Uji coba instrumen dilakukan di kelas X SMAN Jatiwangi, dengan jumlah keseluruhan subjek uji coba sebanyak 30 siswa. Teknik dalam mengumpulkan data pada penelitian pengembangan ini adalah tes tertulis, sedangkan instrumen pengumpulan datanya berupa soal uraian, pilihan ganda dan jawaban singkat. Hasil penelitian menunjukkan bahwa instrumen yang dibuat sebanyak 41 butir soal ini valid dan reliabel. Hal ini berdasarkan perhitungan yang menggunakan rumus Aiken, bahwa nilai $V$-Aiken pada seтиa butir soal $\geq 0,3$, dan dengan nilai Cronbach's Alpha sebesar 0,738. Hasil dari uji coba instrumen ini dapat disimpulkan bahwa kemampuan critical thinking matematika siswa kelas $X$ baik. Hal ini dapat diketahui dari nilai rata-rata hasil uji coba $\geq 65$, yaitu sebesar 70,98 dalam skala 100.
\end{abstract}

Keywords: Analisis Kesalahan, Critical Thinking Skill, Kompetensi Inti, Kurikulum 2013, Penelitian Pengembangan, Pengukuran.

\section{PENDAHULUAN}

Pendidikan mempunyai peranan penting untuk meningkatkan kualitas sumber daya manusia (SDM), karena pendidikan merupakan salah satu sarana untuk menghasilkan perubahan pada diri manusia. Siswa, sebagai manusia pembelajar di sekolah, memiliki banyak sekali potensi pada diri mereka yang merupakan sumber daya manusia. Oleh karena itu, pendidikan merupakan hal yang sangat penting yang dibutuhkan siswa.

Hal tersebut sesuai dengan tujuan pengembangan dalam kurikulum 2013 yang berdasarkan atas landasan filosofis. Permendikbud No. 69 tahun 2013 menyatakan bahwa kurikulum 2013 dikembangkan berdasarkan landasan filosofis yang memberikan dasar bagi pengembangan seluruh potensi peserta didik menjadi manusia Indonesia berkualitas yang tercantum dalam tujuan pendidikan nasional. Adapun tujuan pendidikan nasional telah dicantumkan oleh pemerintah dalam
Undang-Undang Sistem Pendidikan Nasional RI No. 20 Tahun 2003 yaitu:

Pendidikan Nasional bertujuan untuk berkembangnya potensi peserta didik agar menjadi manusia yang beriman, bertaqwa kepada Tuhan Yang Maha Esa, berakhlak mulia, sehat, berilmu, cakap, kreatif, mandiri dan menjadi warga negara yang demokratis serta bertanggung jawab.

Peran pendidikan di sekolah yang terdapat dalam kurikulum, berfokus untuk mengembangkan sumber daya manusia seperti kognitif, afektif dan psikomotorik, atau sikap spiritual, sikap sosial, pengetahuan dan keterampilan.Berpikir kritis adalah istilah yang umumnya dikaitkan dengan kemampuan berpikir tingkat tinggi yang ditandai dengan analisis yang cermat dan pertimbangan. Setiap orang mengharapkan lembaga pendidikan dapat membuat siswa untuk berpikir kritis. Berpikir kritis adalah self-guided, yakni berpikir disiplin diri yang mencoba untuk mencapai kualitas tingkat tertinggi dengan cara berpikiran adil (Conklin, 2012). 
Orang-orang yang berpikir kritis secara konsisten berusaha untuk hidup secara rasional, cukup, dan empati. Orang-orang yang berpikir kritis, ketika dihadapkan suatu permasalahan, pemikiran kritisnya akan mendorong terus untuk tetap belajar menyelesaikan permasalahan tersebut. Mereka berkomitmen untuk berpikir logis tentang permasalahan sampai akhirnya selesai. Mereka berjuang untuk menyingkirkan bias yang datang ke dalam pemikirannya dan berusaha untuk melihat situasi dengan cara baru sehingga dapat dianalisis dan dievaluasi secara logis, dan mereka merefleksikan apa yang sudah mereka pelajari.

Menurut Murray (2011), kemampuan berpikir kritis (critical thnking skill) merupakan bagian dari kemampuan berpikir tingkat tinggi (higher order thinking skills, HOTS). HOTS merupakan salah satusumber daya manusia, yang dalam hal ini adalah pengetahuan dan keterampilan, sehingga harus ditingkatkan dan dikembangkan. Oleh karena itu, salah satu indikasi keberhasilan peningkatan sumber daya manusia dalam bidang pendidikan adalah siswa memiliki kemampuan berpikir tingkat tinggi (HOTS) yang baik, karena tujuan utama pembelajaran pada abad 21 ini, adalah untuk mengembangkan dan meningkatkan HOT siswa (Yen \& Halili, 2015).

Khususnya dalam pelajaran matematika, kemampuan berpikir kritis (bagian dari HOTS) merupakan salah satu yang prioritas untuk dikembangkan. Mengikuti Peraturan Menteri No. 22 tahun 2006, Standar Isi untuk mata pelajaran matematika menyatakan bahwa matematika perlu diberikan kepada semua peserta didik mulai dari sekolah dasar untuk membekali peserta didik dengan kemampuan berpikir logis, analitis, sistematis, kritis, dan kreatif, serta kemampuan bekerjasama.

Agar siswa dapat mengembangkan kemampuan tersebut, maka kemampuan berpikir kritis (bagian dari HOTS) harus biasa dilatihkan. Dengan demikian, dalam proses pembelajaran di kelas guru perlu memberikan soal-soal atau latihan yang memuat HOTS, atau ketika mengadakan suatu tes/ujian seperti ulangan harian, UTS atau UKK, guru memberikan soal-soal yang memuat HOTS, walaupun hanya beberapa butir soal saja. Suatu kemampuan apapun selalu membutuhkan latihan, sedangkan latihan untuk dapat mengembangkan HOTS siswa adalah dengan mengerjakan soal-soal yang memuat HOTS. Hal tersebut sesuai dengan yang disampaikan oleh CCEA (Council for Curriculum, Assessment and Examinations), bahwa guru dan praktisi harus memiliki beberapa panduan praktis tentang bagaimana keterampilan berpikir dapat ditingkatkan dalam tahun pertama anak masuk sekolah, dan bagaimana untuk menilai apakah anak-anak berpikir dengan cara yang konstruktif atau tidak (Walsh, Murphy, \& Dunbar, 2007).

Kegiatan yang dilakukan oleh guru untuk mengetahui kemampuan berpikir kritis (bagian dari HOTS) siswa disebut kegiatan pengukuran, karena kegiatan apapun yang dilakukan di dunia ini tidak lepas dari pengukuran (Mardapi, 2012). Keberhasilan guru melakukan uji coba kepada siswa, seperti memberikan tes yang memuat soal HOTS, dapat diketahui melalui suatu pengukuran. Hasil pengukuran yang dilakukan oleh guru, dapat dipercaya apabila dalam beberapa kali guru tersebut melakukan pengukuran terhadap subjek yang sama, diperoleh hasil yang relatif sama (reliabel). Hal itu akan berlaku jika instrumen yang diukur tidak berubah.

Selain reliabel, instrumen yang akan dijadikan sebagai pengukur oleh guru, harus diestimasi terlebih dahulu kevalidannya. Suatu instrumen pengukur dapat dikatakan mempunyai validitas yang tinggi jika instrumen yang dibuat menjalankan fungsi ukurnya (Azwar, 2011). Apabila suatu instrumen menghasilkan data yang tidak relevan dengan tujuan pengukuran (tidak sesuai dengan fungsi ukur), maka instrumen tersebut memiliki kevalidan yang rendah.

Mencermati hal di atas, hendaknya guru dapat membuat atau mengembangkan instrumen HOTS yang valid dan reliabel. Menurut Conklin (2012) menyatakan bahwa higher order thinking skills (HOTS) meliputi beripikir kritis dan berpikir kreatif. Oleh karena itu, berpikir kritis digunakan dalam upaya memecahkan masalah (problem solving). Berdasarkan hal tersebut, guru dapat membuat atau mengembangkan instrumen yang memuat indikator berpikir kritis untuk memecahkan suatu permasalahan. Hal ini penting dilakukan, karena menurut Depdikbud (2013) melatih 
HOTS siswa merupakan tujuan kurikulum yang termuat dalam Kerangka Dasar dan Struktur Kurikulum SMA/MA dantuntutan bagi guru yang tercantum pada Standar Kompetensi Lulusan Pendidikan Dasar dan Menengah.

Pada Ujian Nasional (UN), mulai tahun ajaran 2013/2014, pemerintah sudah mencantumkan soal-soal yang memuat kemampuan berpikir kritis (bagian dari HOTS). Khususnya pada soal UN matematika pada jenjang SMA/MTs, sudah memuat soal HOTS berupa soal olimpiade intenasional sebanyak 2 soal dari 40 soal atau sebesar 5\%. Diperkirakan untuk pelaksanaan UN tahun berikutnya, soal-soal olimpiade internasionalnya akan lebih banyak, dan terbukti di tahun 2017/2018, UN memuat soal HOTS.

Hal ini merupakan salah satu yang mendasari guru untuk dapat membuat atau mengembangkan instrumen kemampuan berpikir kritis (bagian dari HOTS), yaitu instrumen yang mengukur beberapa aspek kemampuan berpikir kritis (bagian dari HOTS) siswa. Soal pada UN di atas, instrumen kemampuan berpikir kritis merupakan salah satu instrumen yang dapat dirujuk oleh guru. Tujuannya tidak lain adalah mengidentifikasi kekuatan relatif siswa dan kelemahan berpikir tingkat tinggi siswa (Collins, 2010: 4). Di samping itu juga, guru dapat mengetahui kesiapan mereka untuk mengikuti Ujian Nasional. Jika guru tidak melakukan hal tersebut, dikhawatirkan potensi HOTS yang ada pada diri siswa tidak diketahui dan tidak berkembang.

Memang tidak mudah untuk membuat atau mengembangkan instrumen sebagai pengukur higher order thinking skills (HOTS) siswa (Thompson, 2008; Collins, 2014). Namun jika ada kemauan maka kesulitan itu akan dapat diatasi. Seberapa banyak butir pengukur kemampuan berpikir kritis (bagian dari HOTS) harus diberikan, tergantung pada tujuan dilakukan penilaian dan jenjang pendidikan. Semakin tinggi tingkat pendidikan seseorang, semakin banyak pula butir-butir pengukur higher order thinking skills (HOTS) (Kartowagiran, 2011).

Berdasarkan data pada TIMSS yang ditulis oleh Mullis, et.al (2012), posisi Indonesia pada domain kognitif penalaran dan domain konten bilangan masing-masing berada pada peringkat terakhir dan peringkat ke-37 dari 43 negara. Berdasarkan jenis kelamin (gender) yang diperoleh dari data TIMSS juga, menginformasikan bahwa dari tahun 2007 ke 2011 indonesia mengalami penurunan nilai. Hal tersebut dapat dilihat pada Gambar 1 berikut ini.



Gambar 1. Grafik Nilai Perwakilan Indonesia Berdasarkan Data TIMSS. (Sumber: Mullis, et.al, 2012)

Keterangan:

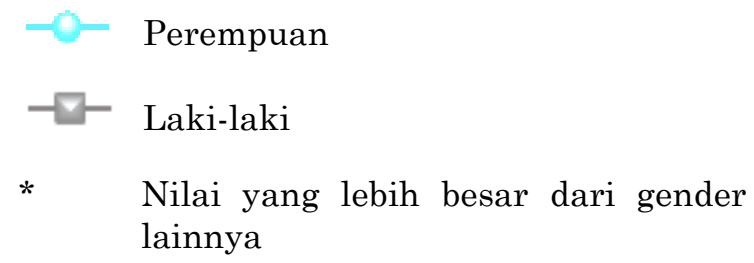

Jika dibandingkan dengan negara-negara tetangga, seperti Malaysia, Singapura, dan Thailand, kemampuan perwakilan dari masing-masing negara tesebut berada di atas kemampuan perwakilan dari negara Indonesia. Perhatikan Gambar-Gambar berikut ini yang diperoleh dari data TIMSS. 


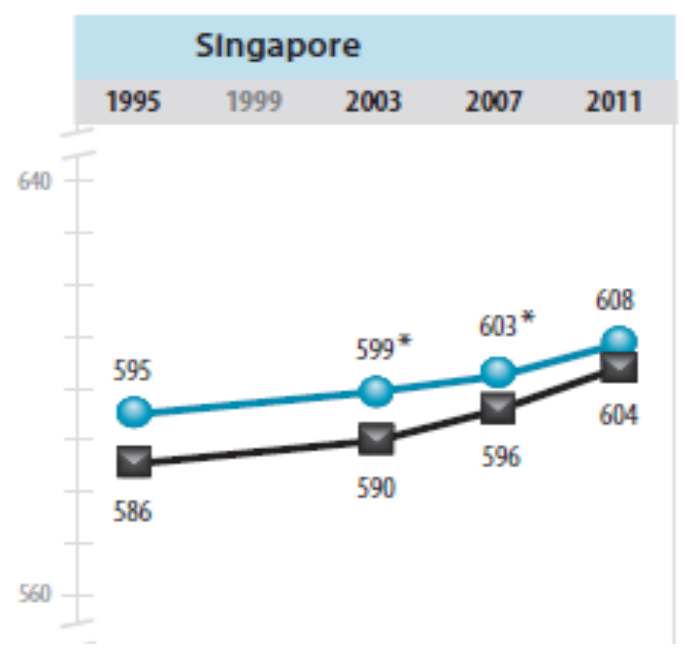

Gambar 2. Grafik Nilai Perwakilan Singapura Berdasarkan Data TIMSS. (Sumber: Mullis, et.al, 2012)

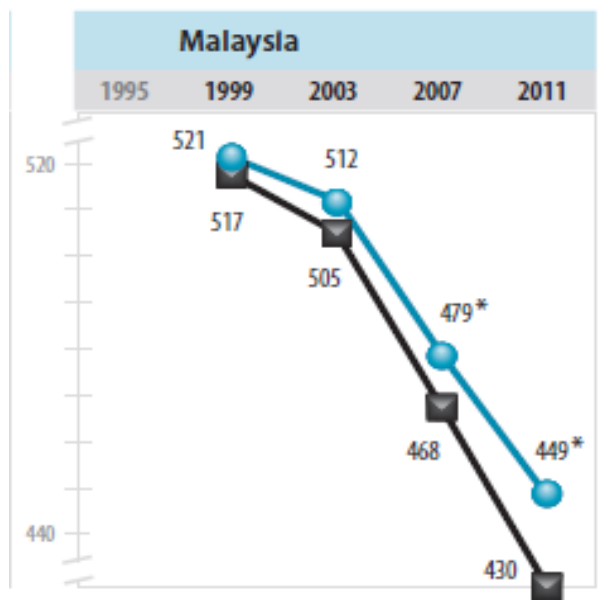

Gambar 3. Grafik Nilai Perwakilan Malaysia Berdasarkan Data TIMSS. (Sumber: Mullis, et.al, 2012)

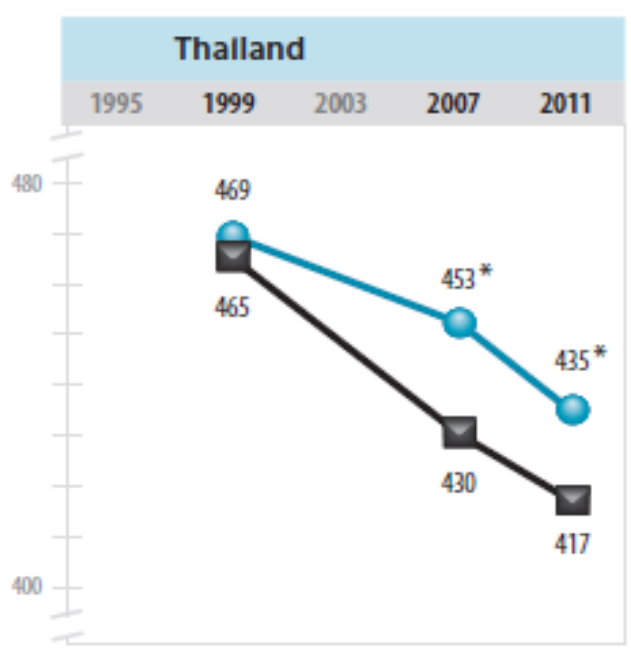

Gambar 4. Grafik Nilai Perwakilan Thailand Berdasarkan TIMSS. (Sumber: Mullis, et.al, 2012:)

Berdasarkan Gambar 2 dapat diketahui bahwa perwakilan dari Singapura memiliki kemampuan yang sangat baik. Hal ini dapat dilihat garis pada grafik yang semakin naik ke atas setiap tahunnya, baik perwakilan laki-laki maupu perwakilan perempuannya. Selain itu, didukung oleh laporan penelitian dari Fullan \& Watson (2011), bahwa di Singapura higher order thinking skills menjadi pusat perhatian dalam bidang pendidikan. Hal ini dapat dilihat dalam data TIMSS (Mullis, et.al., 2012: 40), bahwa skor rata-rata dari perwakilan dari Singapura sebesar 606.

Pada Gambar 3 menunjukkan bahwa kemampuan dari perwakilan Malaysia berada di atas kemampuan perwakilan Indonesia. Walaupun setiap tahunnya nilai mereka menurun. Selain itu, Gambar 4 menginformasikan bahwa kemampuan dari perwakilan Thailand juga berada di atas kemampuan perwakilan Indonesia.

Salah satu dugaan peneliti mengenai hal tersebut adalah karena siswa tidak terbiasa mengerjakan soal-soal yang memuat berpikir kritis (bagian dari HOTS), baik dalam proses pembelajaran atau ketika tes seperti ulangan harian, UTS, maupun UKK. Hal ini didukung oleh hasil survei berupa wawancara yang dilakukan peneliti di SMAN Jatiwangi Kab. Majalengka, yaitu guru belum terbiasa memberikan soal-soal yang memuat kemampuan berpikir kritis (bagian dari HOTS) kepada siswa. Peneliti berpendapat bahwa guru belum terbiasa memberikan soalsoal yang memuat HOTS kepada siswa. Asumsi ini didukung penelitian yang dilakukan oleh Khan (2011), bahwa guru jarang sekali memberikan soal-soal yang memiliki level tinggi. Oleh karena itu, Peneliti menyimpulkan bahwa belum banyak mengenai acuan atau contoh mengenai instrumen yang memuat HOTS.

Berdasarkan hal tersebut, peneliti berpikir bahwa membuat dan mengembangkan instrumen berpikir kritis (bagian dari HOTS) merupakan sesuatu yang perlu dilakukan. Hal ini didukung oleh banyaknya penelitian yang menggunakan metode pembelajaran untuk meningkatkan kemampuan berpikir kritis siswa, sehingga pengembangan 
instrumen pengukur berpikir kritis (bagian dari HOTS) menjadi sesuatu yang sangat penting. Peneliti berharap dengan mengembangkan instrumen ini akan membantu guru-guru yang belum memahami bagaimana cara membuat atau mengembangkan instrumen kemampuan berpikir kritis (bagian dari HOTS), sehingga guru akan terbiasa memberikan soal-soal yang memuat berpikir kritis (bagian dari HOTS) kepada siswa dan mengetahui seberapa besar kemampuan berpikir kritis (bagian dari HOTS) siswa.

\section{KAJIAN PUSTAKA}

\section{A. Critical Thinking Skill dan Higher Order Thinking Skills (HOTS) \\ Teori higher order thinking (HOT)} merupakan jenis pemikiran yang memerlukan proses kognitif lebih besar dari jenis berpikir lainnya (Crumpler, 2014). Brookhart (2010) menyatakan bahwa definisi higher order thinking dikategorikan menjadi tiga, yaitu: sebagai transfer, berpikir kritis dan pemecahan masalah.

1. Definisi higher order thinking
dikategorikan
(perpindahan)

Dua dari tujuan pendidikan yang paling penting adalah retensi dan transfer ilmu ketika pembelajaran berlangsung yang mengindikasikan pembelajaran bermakna (Anderson \& Krathwohl, 2012: 94). Retensi mengharuskan siswa mengingat apa yang telah mereka pelajari, sedangkan transfer menuntut siswa tidak hanya mengingat tetapi juga untuk memahami dan dapat menggunakan apa yang telah mereka pelajari.

2. Definisi Higher Order Thinking dikategorikan sebagai critical Thinking (berpikir kritis)

Berpikir kritis adalah berpikiryang difokuskan ketika memutuskan apa yang harus dipercaya atau dilakukan. Brookhart (2010: 4) menyebutkan bahwa yang termasuk berpikir kritis menurut Barahal $^{1}$ adalah meliputi reasoning (penalaran), questioning (mempertanyakan) dan investigating (menyelidiki), observing (mengamati) dan describing (menggambarkan), comparing (membandingkan) dan connecting (menghubungkan), menemukan kompleksitas, dan menjelajahi sudut pandang.

3. Definisi Higher Order Thinking dikategorikan sebagai problem solving (pemecahan masalah).

Definisi problem solving dikategorikan menjadi dua, yaitu:

a. Seorang siswa menemukan masalah ketika ia ingin mencapai hasil atau tujuan tertentu, yaitu tidak secara otomatis mengenali jalan atau cara yang digunakan untuk mencapai hasil tersebut. Masalah yang dihadapinya membuat ia untuk mencapai tujuan yang diinginkan, karena siswa tersebut tidak dapat secara otomatis mengenali cara yang tepat untuk mencapai tujuan yang diinginkan. Oleh karena itu, ia harus menggunakan satu atau lebih proses berpikir tingkat tinggi. Proses-proses berpikir itu disebut pemecahan masalah.

b. Pemecahan masalah merupakan suatu model yang dapat diterapkan untuk masing-masing masalah dalam membantu seseorang terus belajar sendiri, juga menyusun strategi otomatik yang diperlukan untuk mencapai suatu tujuan.

Nada serupa dinyatakan oleh Murray (2011), bahwa higher order thinking skills meliputi konsep berpikir kritis, pemecahan masalah, berpikir kreatif, dan pengambilan keputusan. Selain itu, Conklin (2012) \& Heong (2011) menyatakan bahwa higher orderthinking skillsmeliputi beripikir kritis dan berpikir kreatif. Pada revisi taksonomi Bloom, proses kognitif yang terjadi ketika siswa aktif adalah menganalisis (analyzing), mengevaluasi (evaluating), dan mencipta (creating) (Conklin, 2012). Proses kognitif tersebut dapat meningkatkan higher order thinking siswa.

Lebih luasnya higher order thinking skills didefinisikan didalamnya termasuk berpikir kritis, logis, reflektif, metakognisi dan kreatif (King, Goodson, \& Rohani, 2010). Semua kemampuan tersebut aktif ketika seseorang berhadapan dengan masalah yang tidak biasa, ketidakpastian, pertanyaan dan pilihan. Higher order thinking skills tidak hanya diterapkan ketika di sekolah saja, tapi diterapkan juga dalam kehidupan nyata (Williams, 2003).

Seorang siswa dikatakan mampu menyelesaikan masalah apabila ia dapat menerapkan pengetahuan yang telah 
diperoleh sebelumnya ke dalam situasi baru yang belum dikenal. Kemampuan inilah yang dikenal sebagai keterampilan berpikir tingkat tinggi (Setiawan, Dafik, \& Lestari, 2014). Kemampuan ini merupakan kemampuan yang paling sulit dalam menumbuhkan berpikir siswa di sekolah, karena kemampuan ini berada di luar langkah-langkah pembelajaran tradisional (Goethals, 2013).

\section{B. Keterkaitan Taksonomi Bloom dan}

Critical Thinking Skill

Taksonomi Bloom mengklasifikasikan perilaku intelektual menjadi enam tingkat berpikir. Tingkat terendah dari tingkatan berpikir tersebut memerlukan pengakuan dasar atau recall, sedang tingkat tertingginya memerlukan pemikiran kritis dan kreatif (Conklin, 2012). Taksonomi Bloom memiliki peran penting dalam membantu kita memahami kemampuan berpikir kritis melalui proses kognitif menganalisis (analyzing), mengevaluasi (evaluating) (Anderson \& Krathwohl, 2012).

1. Menganalisis (analyzing)

Menganalisis meliputi kemampuan untuk memecah suatu kesatuan menjadi bagian-bagian dan menentukan bagaimana bagian-bagian tersebut dihubungkan satu dengan yang lain atau bagian tersebut dengan keseluruhannya. Analisis menekankan pada kemampuan merinci sesuatu unsur pokok menjadi bagian-bagian dan melihat hubungan antar bagian tersebut. Di tingkat analisis, seseorang akan mampu menganalisa informasi yang masuk dan membagi-bagi atau menstrukturkan informasi ke dalam bagian yang lebih kecil untuk mengenali pola atau hubungannya dan mampu mengenali serta membedakan faktor penyebab \dan akibat dari sebuah skenario yang rumit. Kategori menganalisis terdiri kemampuan membedakan (differentiating), mengorganisasi (organizing), dan mengatribusikan (attributing).

\section{a. Membedakan (differentiating)}

Membedakan meliputi kemampuan membedakan bagian-bagian dari keseluruhan struktur dalam bentuk yang sesuai. Membedakan terjadi sewaktu siswa mendeskriminasikan informasi yang relevan dan tidak relevan, yang penting dan tidak penting, dan kemudian memperhatikan informasi yang relevan dan penting. Membedakan berbeda dengan proses-proses kognitif dalam kategori memahami, karena membedakan melibatkan proses mengorganisasi secara struktural dan menentukan bagaimana bagian-bagian sesuai dengan struktur keseluruhannya.

b. Mengorganisasi (organizing)

Mengorganisasi meliputi kemampuan mengidentifikasi unsur-unsur secara bersama-sama menjadi struktur yang saling terkait. Proses mengorganisasi terjadi ketika siswa membangun hubungan-hubungan yang sistematis dan koheren (terkait) antar potongan informasi. Mengorganisasi juga biasanya terjadi bersamaan dengan proses membedakan. Siswa mula-mula mengidentifikasi elemen-elemen yang relevan atau penting dan kemudian menentukan sebuayh struktur yang terbentuk dari elemen-elemen itu. Mengorganisasi juga bias terjadi bersamaan dengan proses mengatribusikan, yang fokusnya adalah menentukan tujuan atau sudut pandang seseorang, seperti pengarang, penulis, atau pembuat soal.

c. Mengatribusikan (attributing)

Mengatribusikan adalah kemampuan siswa untuk menyebutkan tentang sudut pandang, bias, nilai atau maksud dari suatu masalah yang diajukan. Mengatribusikan membutuhkan pengetahuan dasar yang lebih agar dapat menarik kesimpulan atau maksud dari inti permasalahan yang diajukan. Mengatribusikan juga melibatkan proses dekonstruksi, yang didalamnya siswa menentukan tujuan dari suatu permasalahan yang diberikan oleh guru.

\section{Mengevaluasi (evaluate)}

Mengevaluasi didefinisikan sebagai kemampuan melakukan judgement berdasar pada kriteria dan standar tertentu. Kriteria sering digunakan adalah menentukan kualitas, efektifitas, efisiensi, dan konsistensi, sedangkan standar digunakan dalam menentukan kuantitas maupun kualitas. Evaluasi mencakup kemampuan untuk membentuk suatu pendapat mengenai sesuatu atau beberapa hal, bersama dengan pertanggungjawaban pendapat itu yang berdasar kriteria tertentu. Adanya kemampuan ini dinyatakan dengan memberikan penilaian terhadap sesuatu. Kategori menilai terdiri dari memeriksa (checking) dan mengkritik (critiquing).

a. Memeriksa (checking)

Memeriksa adalah kemampuan untuk mengetes atau menguji konsistensi internal atau kesalahan pada operasi atau hasil serta mendeteksi keefektifan prosedur yang digunakan. Jika dipadukan dengan dengan merencanakan (proses kognitif dalam kategori mencipta) dan 
mengimplementasikan (proses kognitif dalam kategori mengaplikasikan), memeriksa melibatkan proses menentukan seberapa baik rencana itu berjalan.

b. Mengkritik (critiquing)

Mengkritik adalah kemampuan memutuskan hasil atau operasi berdasarkan kriteria dan standar tertentu, dan mendeteksi apakah hasil yang diperoleh berdasarkan suatu prosedur menyelesaikan suatu masalah mendekati jawaban yang benar. Proses mengkritik terjadi ketika siswa mencatat ciri-ciri positif dan negatif dari suatu produk dan membuat keputusan, setidaknya sebagian berdasarkan ciri-ciri tersebut. Mengkritik merupakan inti dari apa yang disebut berpikir kritis.

C. Ciri-ciri dan Indikator Critical Thinking Skill

Critical thinking skill meliputi proses menganalisis dan mengevaluasi. Proses menganalisis melibatkan proses mental siswa untuk memecah-mecah materi menjadi bagian-bagian kecil. Berbeda dengan proses mengevaluasi dimana siswa melibatkan proses mentalnya untuk membuat keputusan berdasarkan kriteria/standar tertentu. (Anderson \& Krathwohl, 2012: 121-128). Untuk mengukur Critical Thinking Skill seseorang, dapat menggunakan instrumen dengan indikator sebagai berikut:

Tabel 1. Indikator Critical Thinking Skill

\begin{tabular}{|c|c|c|}
\hline HOTS & Indikator & Sub Indikator \\
\hline \multirow{2}{*}{$\begin{array}{c}\text { Berpikir } \\
\text { kritis }\end{array}$} & 1. Analisis & $\begin{array}{l}\text { 1.1 Membedakan } \\
\text { 1.2 Mengorganisasikan } \\
\text { 1.3 } \text { Mengatribusikan }\end{array}$ \\
\hline & 2. Evaluasi & $\begin{array}{l}\text { 2.1 Memeriksa } \\
\text { 2.2 Mengkritik }\end{array}$ \\
\hline
\end{tabular}

\section{METODOLOGI}

a. Populasi dan Sampel

Ujicoba instrumen ini dilakukan di

SMAN 1 Jatiwangi, kelas X.C sebanyak 30 siswa.

b. Desain Penelitian

Jenis penelitian ini termasuk research and development (R\&D), yaitu peneliti mengembangkan instrumen analisis kesalahan untuk mengukur critical thinking skill matematika siswa berdasarkan Kompetensi Inti Kurikulum 2013. Penelitian ini akan menghasilkan sebuah produk berupa instrumen yang dapat dijadikan contoh atau acuan oleh guru untuk dapat mengukur critical thinking siswa dalam pelajaran matematika. Model penelitian ini diadaptasi dari model pengembangan yang dibuat oleh Mardapi (2008), yaitu: (1) menyusun spesifikasi tes, (2) menulis soal tes, (3) menelaah soal tes, (4) melakukan ujicoba tes, (5) menganalisis butir soal, (6) memperbaiki tes, (7) merakit tes, (8) melaksanakan tes, (9) menafsirkan hasil tes. Namun pada penelitian ini, peneliti membatasi model pengembangannya hanya sampai dengan langkah merakit tes saja. Dengan kata lain, peneliti tidak melakukan pelaksanaan tes dan menafsirkan hasil tes. Dua langkah terakhir tersebut peneliti harapkan dapat dilaksanakan oleh guru-guru yang notabene sebagai pengajar di sekolah.

Pada tahapan menelaah instrumen, rumusan dimensi dan indikator yang disusun, direview oleh pembimbing dan validator ahli di bidangnya. Peneliti meminta pendapat berdasarkan keilmuan yang dimilikinya tentang tingkat kesesuaian dan pola pengembangan rekaan teoritis (variabel) ke dalam indikator-indikator hingga menjadi butir-butir soal. Setelah divalidasi oleh ahli di bidangnya, rumusan indikator disusun dalam draft instrumen kemudian diujicobakan pada subjek uji coba.

c. Alur Pengolahan Data

Teknik analisis data yang digunakan dalam penelitian pengembangan ini meliputi:

a. Validitas Isi

Validitas isi ditentukan menggunakan kesepakatan ahli (expert). Kesepakatan ahli bidang studi atau sering disebut dengan domain yang diukur menentukan tingkatan validitas isi. Hal ini dikarenakan instrumen pengukuran dibuktikan valid jika ahli meyakini bahwa bahwa istrumen tersebut mengukur penguasaan kemampuan yang didefinisikan dalam domain ataupun juga konstruk psikologi yang diukur (Retnawati, 2014). Peneliti meminta kepada ahli untuk memeriksa ketepatan antara kesesuaian butir soal dengan indikator-indikatornya, redaksi penulisan soal, dan kesesuaian pilihan jawaban (pengecoh) pada pilihan ganda. Apabila masih ada kekeliruan, maka instrumen tersebut direvisi kembali.

Setelah dilakukan pemeriksaan oleh ahli, selanjutnya ahli memberikan penilaian terhadap instrumen. Penilaian tersebut terdiri dari 4 kriteria sebagai berikut:

Tabel 2. Kriteria Penilaian Butir Instrumen oleh Validator

\begin{tabular}{|c|c|}
\hline Nilai & Keterangan \\
\hline 1 & Tidak Relevan \\
\hline 2 & Kurang Relevan \\
\hline
\end{tabular}




\begin{tabular}{|c|c|}
\hline 3 & Cukup \\
\hline 4 & Relevan \\
\hline 5 & Sangat Relevan \\
\hline
\end{tabular}

Setelah diberikan penilaian oleh ahli, selanjutnya peneliti menghitung hasil penilaian menggunakan indeks validitas, diantaranya dengan indeks yang diusulkan oleh Aiken sebagai berikut.

$V=\frac{\sum s}{N(c-1)}$, dimana $s=r-l$

Keterangan:

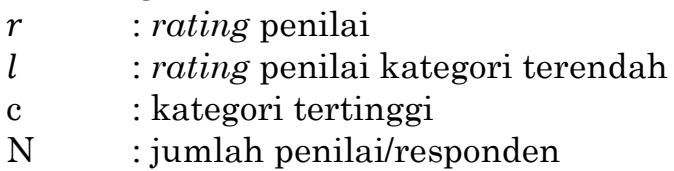

(Aiken, 1980)

Rentang angka Vyang mungkin diperoleh adalah antara 0 sampai dengan 1 . Semakin tinggi angka $V$ (mendekati 1 atau sama dengan 1) maka nilai kevalidan sebuah item/butir soal juga semakin tinggi, dan semakin rendah angka $V$ (mendekati 0 atau sama dengan 0) makan nilai kevalidan sebuah item/butir soal juga semakin rendah (Aiken, 1980).

b. Estimasi Reliabilitas Instrumen

Teknik analisis data untuk estimasi reliabilitas instrumen ini menggunakan teknik estimasi konsistensi internal dengan formula Chronbach-alpha yang dibantu aplikasi SPSS IBM 20. Jika nilaiCronbach's Alpha 0,60 dan kurang dari 1, maka instrumen tersebut memiliki korelasi tinggi atau reliabel, sedangkan jika nilai Cronbach's Alpha di bawah 0,50 ke bawah, maka instrumen tersebut berkorelasi rendah atau tidak reliabel (Basuki dan Hariyanto, 2014). Hal ini juga didukung oleh Surapranata (2009), bahwa koefisien reliabilitas sebesar 0,5 dapat digunakan untuk tujuan penelitian.

\section{c. Kemampuan Critical Thinking Matematika Siswa}

Teknik analisis data yang digunakan peneliti untuk mengetahui kemampuan critical thinking matematika siswa, yaitu $\geq$ 65. Artinya, jika siswa memperoleh nilai $\geq 65$ maka kemampuan critical thinking matematika siswa baik. Namun jika siswa memperoleh nilai < 65 maka kemampuan critical thinking matematika siswa kurang baik.

\section{HASIL DAN PEMBAHASAN}

a. Deskripsi Pengembangan Instrumen

1. Menyusun Spesifikasi Instrumen Tes

a) Menentukan tujuan tes

Tujuan utama peneliti dalam melakukan penelitian pengembangan ini sudah tercantum pada bab pertama, yaitu berdasarkan tujuan dari rumusan masalah yang telah dibuat peneliti. Tujuan utama tersebut adalah sebagai berikut:

1) Untuk menghasilkan instrumen analisis kesalahan sebagai pengukur critical thinking skill siswa SMA yang valid dan reliabel.

2) Untuk mengetahui kemampuan critical thinking skills siswa SMA setelah diberikan instrumen critical thinking.

b) Menyusun kisi-kisi tes

Menyusun kisi-kisi tes (blueprint) menjadi langkah yang sangat penting. Peneliti menyusun kisi-kisi tes berdasarkan Kompetensi Inti (KI) dan Kompetensi Dasar (KD) Kurikulum 2013 dengan indikator dari kajian mengenai critical thinking skills.

c) Memilih bentuk tes

Bentuk tes atau jenis instrumen yang digunakan pada penelitian pengembangan ini adalah pilihan ganda, jawaban singkat, dan uraian. Bentuk tes ditentukan berdasarkan indikator yang dibuat oleh peneliti yang berdasarkan jenis instrumen analisis kesalahan pengukur critical thinking skill.

\section{d) Menentukan panjang tes}

Dari semua butir soal yang dibuat, peneliti memperhatikan panjang tiap-tiap butir soal yang akan diujikan. Tidak lebih dari setengah halaman untuk satu butir soal. 2. Menulis Soal Instrumen Tes

Peneliti membuat dan mengembangkan instrumen untuk mengukur kemampuan crticial thinking siswa kelas X dalam pelajaran matematika. Instrumen yang dibuat secara keseluruhan mencakup dua semester (satu tahun). Instrumen ini dibuat dari indikator yang berdasarkan Kompetensi Dasar (KD) Kurikulum 2013. Berbantu pada kisi-kisi yang telah dibuat, peneliti berhasil membuat instrumen sebanyak 16 butir soal pada Semester Ganjil dan 25 butir soal pada Semester Genap yang tersedia pada Lampiran.

3. Menelaah Soal Instrumen Tes 
Telaah soal instrumen ini dilakukan oleh 2 ahli/pakar pada pelajaran matematika. Tahap ini disebut proses validasi oleh ahli. Dua validator yang ahli dalam bidang ini adalah Dosen Pendidikan Matematika Universitas Majalengka, dan guru matematika kelas X SMAN Jatiwangi

Hasil dari telaah oleh validator, menunjukkan bahwa instrumen yang dibuat peneliti ada yang harus diperbaiki. Oleh karena itu, peneliti memperbaiki/merevisi semaksimal mungkin saran-saran yang dituliskan pada lembaran-lembaran instrumen yang diberikan oleh validator. Setelah selesai diperbaiki, instrumen tersebut diberikan kembali kepada validator untuk dinilai masing-masing butirnya.

Hasil dari penilaian tersebut dianalisis menggunakan rumus Aiken untuk mengetahui kevalidan masing-masing butir soal, dan nilai $V$-Aiken pada semua butir soal $\geq 0,3$. Oleh karena sudah valid masing-masing butir soalnya, maka instrumen siap untuk diujicobakan.

4. Melakukan Uji Coba Instrumen Tes

Peneliti melaksanakan uji coba instrumen yang sudah divalidasi kepada siswa kelas X SMAN Jatiwangi. Instrumen yang dibuat peneliti adalah instrumen yang diambil dari KI dan KD kurikulum 2013. Selain itu, sekolah tersebut sudah menggunakan Kurikulun 2013, sehingga instrumen yang diujicobakan adalah instrumen yang indikatornya sesuai dengan Kurikulum 2013.

\section{b. Analisis Data}

1. Validitas Instrumen

Sudah dibahas sebelumnya bahwa instrumen yang dibuat, berdasarkan hasil perhitungan rumus Aiken adalah valid, karena nilai $V$ Aiken pada semua butir soal di atas 0,3 .

2. Reliabilitas Instrumen

Tujuan penelitian pengembangan ini, selain ingin menghasilkan instrumen yang valid, juga ingin menghasilkan instrumen yang reliable, yakni dengan Nilai Cronbach's Alpha sebesar 0,738.

\section{Kemampuan Critical Thinking} Matematika Siswa

Tujuan analisis ini adalah untuk mengetahui kemampuan critical thinking matematika siswa. Jika siswa memperoleh nilai $\geq 65$ maka critical thinking matematika siswa tersebut baik, sedangkan jika siswa memperoleh nilai < 65 maka critical thinking matematika siswa kurang baik. Berdasarkan hasil ujicoba, menunjukkan bahwa kemampuan critical thinking matematika siswa pada uji coba masih di atas 65, yaitu dengan hasil nilai rata-rata sebesar 70,98 dalam skala 100 . Nilai rata-rata ini mengidentifikasikan bahwa kemampuan critical thinking matematika siswa pada uji coba baik.

\section{KESIMPULAN DAN SARAN}

a. Kesimpulan

Berdasarkan hasil analisis yang telah peneliti lakukan, dapat diambil kesimpulan sebagai berikut:

1. Berdasarkan perhitungan menggunakan rumus Aiken, instrumen analisis kesalahan untuk mengukur critical thinking skill siswa SMA dikategorikan valid, karena semua nilai $\mathrm{V}$ di atas 0,3 , dan reliabel dengan nilai Cronbach's Alpha sebesar 0,738.

2. Hasil dari uji coba instrumen dapat disimpulkan bahwa kemampuan critical thinking matematika siswa kelas $\mathrm{X}$ baik. Hal ini ditunjukkan dengan nilai rata-rata hasil uji coba yang lebih dari 65 , yaitu sebesar 70,98 dalam skala 100.

b. Saran

Penelitian pengembangan ini menghasilkan sebuah produk instrumen analisis kesalahan untuk mengukur critical thinking skill siswa SMA. Oleh karena itu, bagi guru matematika kelas $\mathrm{X}$ dapat menggunakannya seperti pada Ujian Tengan Semester maupun Ujian Kenaikan Kelas. Selain itu, peneliti lain juga dapat membuat dan mengembangkan instrumen pengukur HOTS matematika siswa kelas XI dan kelas XII, atau kelas VII, VIII, dan IX SMP.

\section{DAFTAR PUSTAKA}

Aiken, L. R. (1980). Content validity and reliability of single items or questionnaires.Educational and psychological measurement, 40(4), 955-959.

Anderson, L. W. \& Krathwohl, D. R. (2010). A taxonomy for learning, teaching, and assessing: A revision of bloom's taxonomy of educational objectives. A bridge Edition. (Terjemahan Agung Prihantoro). New York: Addison Wesley Longman, Inc. (Buku asli diterbitkan tahun 2001). 
Azwar, S. (2011). Reliabilitas dan validitas. Yogyakarta: Pustaka Belajar.

Basuki, I., \& Hariyanto. (2014). Asesemen pembelajaran. Bandung: PT. Remaja Rosdakarya.

Brookhart, S. M. (2010). How to assess higherorder thinking skills in your classroom. Alexandria, Virginia USA: ASCD.

Collins, V. (2010). Higher order thinking (HOT) program assessment plan. Fort Worth, Texas: University of North Texas Health Science Center.

Conklin, W. (2012). Higher-order thinking skills to develop $21^{\text {st }}$ century learners. Huntington Beach, California: Shell Education.

Crumpler, W. (2014). Higher-order skills in critical and creative thinking. New York: NC State University.

Depdikbud. (2013). Peraturan Menteri Pendidikan dan Kebudayaan Nomor 69, Tahun 2013, tentang Kerangka Dasar dan Struktur Kurikulum Sekolah Menengah Atas/Madrasah Aliyah.

Fullan, M., dan Watson, N. (2011). The slow road to higher order skills. Report to stupski foundation.

Goethals, Paul L. (2013). The pursuit of higher-order thinking in the mathematics classroom: a review. United States Military Academy, West Point, NY.

Kartowagiran, B. (2011). Penulisan butir soal. Yogyakarta: Pascasarjana UNY. Makalah disampaikan pada Pelatihan penulisan dan analisis butir bagi guru SMP Provinsi D.I. Yogyakarta pada tanggal 23, 26, dan 28 Juli 2011 di Pascasarjana UNY.

Khan. W.B. (2011). A study of lower-order and higher-order questions at secondary level. Pakistan: Canadian Center of Science and Education. Asian Social Science Vol. 7, No. 9; September 2011.

Mardapi, D. (2008). Teknik penyusunan instrumen tes dan non tes. Yogyakarta: Mitra Cendika.

(2012). Pengukuran, penilaian, \& evaluasi pendidikan. Yogyakarta: Nuha Medika.
Mullis, Ina V.S., et.al, (2012). TIMSS 2011 international results in mathematics.Chestnut Hill, MA, USA: Publisher: TIMSS \& PIRLS International Study Center, Lynch School of Education, Boston College.

Murray, E. C. (2011). Implementing higherorder thinking in middle school mathematics classrooms. Athens: the Graduate School The University of Georgia.

Retnawati, H. (2014). Membuktikan validitas instrumen dalam pengukuran. Diambil pada tanggal 8 Juli 2015 dari http://www.evaluation-edu.com.

Setiawan, H., Dafik, dan Lestari, N., Diah Sri. (2014). Soal matematika dalam pisa kaitannya dengan literasi matematika dan keterampilan berpikir tingkat tinggi. Universitas Jember: Prosiding Seminar Nasional Matematika, Universitas Jember, 19 November 2014.

Shin Yen, Tan dan Halili, Siti Hajar. (2015). Effective teaching of higher-order thinking (hot) in education. The Online Journal of Distance Education and e-Learning (TOJDEL). Volume 3, Issue 2.

Surapranata, S. (2009). Analisis, validitas, reliabilitas, dan interpretasihasil tes implementasi kurikulum 2004. Bandung: PT. Remaja Rosdakarya.

Thompson, T. (2008). Mathematics teachers' interpretation of higher-order thinking in bloom's taxonomy. International Electronic Journal ofMathematics Education, Volume 3, Number 2, July 2008.

Walsh, G., Murphy P, and Dunbar, C. (2007). Thinking Skills in the Early Years: A Guide for Practitioners. Stranmillis University College.

Williams, R. Bruce. (2003). Higher order thinking skills. Challenging all students to achieve. California: Corwin Press. 